\title{
Alphavirus Vectors in Vaccine Development
}

\section{Kenneth Lundstrom*}

PanTherapeutics, Lutry, Switzerland

\begin{abstract}
The high-level heterologous gene expression provided by alphavirus vectors has accelerated their applications in vaccine development. The versatility of alphavirus vectors has allowed their use in the form of recombinant viral particles, naked RNA and layered DNA molecules for immunization. The most commonly used alphaviruses have been Semliki Forest virus, Sindbis virus and Venezuelan Equine Encephalitis virus. Numerous viral structural proteins have been used as antigens to generate neutralizing antibodies in immunized animals. Vaccination has demonstrated protection against challenges with lethal doses of viruses. Moreover, vaccination with tumor antigens has demonstrated prophylactic protection against cancer. Novel approaches include the application of RNA interference and microRNA. The other side of the coin is the development of vaccines against alphaviruses themselves, and typically the Chikungunya virus.
\end{abstract}

Keywords: Alphaviruses; Viral vectors; DNA vaccines; Neutralizing antibodies; Protection against viral; Tumor challenges

\section{Introduction}

The members of alphaviruses belong to the Togaviridae. They possess a single stranded RNA genome, which together with the capsid forms the nucleocapsid surrounded by membrane proteins embedded in a liposome envelope structure [1]. A number of alphaviruses has demonstrated pathogenicity among them recently Chikungunya with global fever epidemics [2]. Although Semliki Forest Virus (SFV) has been associated with an outbreak of febrile illness in Central Africa [3] and Venezuelan Equine Encephalitis (VEE) Virus with an epidemic in horses and humans in South America [4], attenuated strains has been the basis for the development of safe and efficient expression vectors. In this context, SFV [5], Sindbis virus (SIN) [6] and VEE [7] vectors have been engineered for heterologous gene expression.

The most common approach has been to generate replication-deficient alphavirus vectors. These can be used for vaccine development in three variations (Figure 1). Naked RNA consisting of the nonstructural

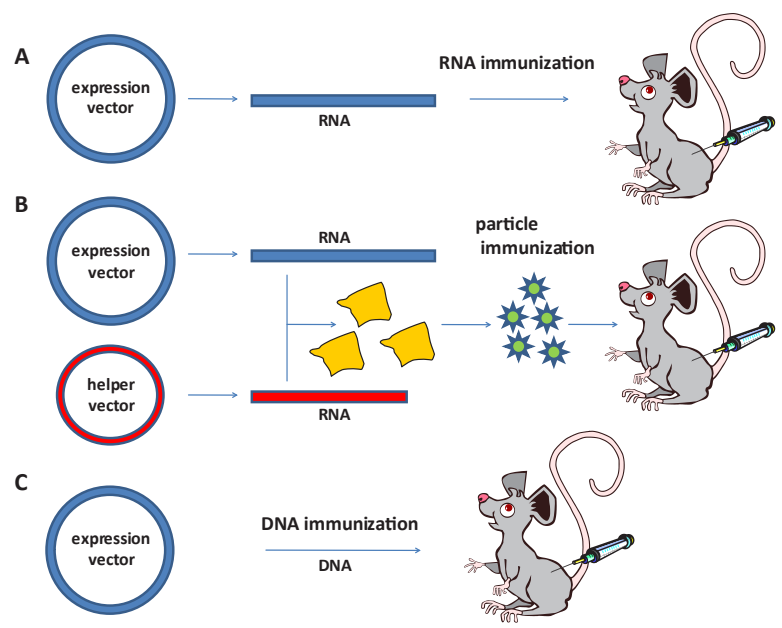

Figure 1: Alphavirus vectors applied in vaccine development. A. Naked RNA vector: In vitro transcribed RNA is directly injected into animals. B. Replication-deficient recombinant particles: Replicon particles are obtained from in vitro transcribed RNA from expression and helper vectors after co-electroporation of BHK-21 cells. C. Layered DNA vectors: Plasmid DNA can be used directly for immunization. replicase genes and the antigen generating gene downstream of the strong subgenomic promoter can be administered as such. Moreover, replication-deficient recombinant alphavirus particles providing infection capacity of a broad range of host cells without any further production of virus progeny are potential vehicles for immunization. Finally, layered DNA vectors, which provide the replicase genes and antigen of interest in DNA form, can be applied. In all approaches advantage is taken of the extremely efficient RNA replication of some 200,000 RNA copies from each RNA molecule due to the presence of the alphaviral replicase genes. The most significant differences are related to delivery and safety aspects described later in the review. A number of topologically different recombinant proteins have been expressed from particularly SFV vectors [8]. Typically, high expression levels of integral membrane proteins have been obtained in various mammalian host cell lines [9], in primary neurons [10], and in vivo [11]. In the context of vaccine development, the three main vector systems (SFV, SIN and VEE) have been applied in the forms of naked RNA, recombinant virus particles and layered DNA vectors [12]. As described below viral and tumor antigens have been administered in various animal models to elicit neutralizing antibodies and protection against challenges with tumor cells or lethal doses of viruses.

\section{Viral Vaccine Approaches}

The obvious targets for vaccine development have been viral structural proteins [12] (Table 1). For instance, influenza nucleoprotein (NP) and hemagglutinin (HA) have generated strong immune responses in rodents [13] and even protection against challenges with H5N1 virus in chicken [14]. Moreover, several studies have been conducted on HIV targets (env, gp41, MA/CA) in attempts to elicit antibody responses in mice [15-17]. Additionally, immunization

*Corresponding author: Kenneth Lundstrom, PanTherapeutics, Lutry, Switzerland, E-mail: lundstromkenneth@googlemail.com

Received October 21, 2012; Accepted June 14, 2012; Published June 20, 2012

Citation: Lundstrom K (2012) Alphavirus Vectors in Vaccine Development. J Vaccines Vaccin 3:139. doi:10.4172/2157-7560.1000139

Copyright: ( 2012 Lundstrom K. This is an open-access article distributed under the terms of the Creative Commons Attribution License, which permits unrestricted use, distribution, and reproduction in any medium, provided the original author and source are credited. 


\begin{tabular}{|c|c|c|c|c|c|}
\hline Virus & Target & Vector/Delivery & Immunization & Response & Reference \\
\hline NS3 (p80) & SFV / DNA & Mouse & CTL & CMI & [63] \\
\hline CSFV & E2 & SFV / DNA & Swine & CSFV protection & [24] \\
\hline EAV & G, L, M & VEE / Particles & Mouse & Neutralizing Abs & [64] \\
\hline \multirow[t]{3}{*}{ Ebola } & NP & VEE / Particles & Mouse & Ebola protection & [18] \\
\hline & NP, GP & VEE / Particles & Guinea pig & Ebola protection & [65] \\
\hline & VP24, 30, 35, 30 & VEE / Particles & Mouse & Ebola protection & [66] \\
\hline \multirow[t]{2}{*}{ Hepatitis B } & $\mathrm{cAg}$ & SIN / DNA & Mouse & Specific Abs & [67] \\
\hline & $\mathrm{sAg}$ & SIN / DNA & Mouse & Specific Abs & [67] \\
\hline \multirow[t]{2}{*}{ Hepatitis C } & $\mathrm{cAg}$ & SFV / Particles, DNA & Mouse & CTL & [68] \\
\hline & NS3 & SFV / Particles & Mouse & Cellular & [69] \\
\hline $\mathrm{HeV}$ & Glycoprotein & VEE / Particles & Mouse & Neutralizing Abs & [25] \\
\hline \multirow[t]{3}{*}{ HIV-1 } & env & SFV / Particles & Mouse & Humoral & [15] \\
\hline & gp41 & SFV / Particles & Mouse & Monoclonal Abs & [16] \\
\hline & $\mathrm{MA} / \mathrm{CA}$ & VEE / Particles & Mouse & Humoral, CTL & [17] \\
\hline \multirow[t]{3}{*}{$\mathrm{HPV}$} & 16E7 & SFV / DNA & Mouse & CTL & [70] \\
\hline & 16E7-VP22 & SIN / Particles & Mouse & CD8+ T cell response & [71] \\
\hline & E7-hsp70 & SIN / Particles & Mouse & CTL & [72] \\
\hline \multirow[t]{2}{*}{ HSV-1 } & gpB & SIN / Particles & Mouse & HSV protection & [73] \\
\hline & $\mathrm{gpB}$ & SIN / DNA & Mouse & CTL, protection & [74] \\
\hline IBDV & VP2 & SFV / Particles, DNA & \multicolumn{2}{|c|}{ Chicken Specific Abs } & [75] \\
\hline \multirow[t]{7}{*}{ Influenza } & $\mathrm{HA}$ & SFV / Particles & Mouse & Systemic response & [13] \\
\hline & HA & SFV / DNA & Mouse & Humoral, cellular & [76] \\
\hline & HA & VEE / Particles & Chicken Influ & za protection & [14] \\
\hline & HA & VEE / Particles & Swine & Influenza protection & [20] \\
\hline & $\mathrm{HA}$ & VEE / Particles & Swine & Specific Abs & [21] \\
\hline & NP & SFV / Particles, RNA & Mouse & Humoral, CTL & [77] \\
\hline & NP & SFV / Particles, RNA & Mouse & CTL & [78] \\
\hline JEV & prM-E, NS1-2A & SIN / Particles & Mouse & JEV Abs & [79] \\
\hline Lassa & $\mathrm{N}$ & VEE / Particles & Mouse & Immune response & [19] \\
\hline \multirow[t]{2}{*}{ LIV } & prME & SFV / Particles & Mouse & LIV protection & [80] \\
\hline & prME, NS1 & SFV / Particles & Sheep & LIV protection & [81] \\
\hline \multirow[t]{2}{*}{ MBGV } & GP, NP, VP35 & VEE / Particles & Guinea pig & MBGV protection & [82] \\
\hline & GP, NP & VEE / Particles & Macaques & MBGV protection & [83] \\
\hline \multirow[t]{2}{*}{ Measles } & HA, FUd & SIN / DNA & Mouse & Measles protection & [29] \\
\hline & HA, FUd & SIN-VEE / Particles & Macaques & Measles protection & [30] \\
\hline MVE & prME, E & SFV / Particles & Mouse & Neutralizing Abs & [84] \\
\hline $\mathrm{NiV}$ & Glycoproteins & VEE / Particles & Mouse & Neutralizing Abs & [25] \\
\hline NLV & VLP & VEE / Particles & Mouse & Immune response & [85] \\
\hline Rabies & G & SIN / DNA & Mouse & Rabies protection & [32] \\
\hline \multirow[t]{2}{*}{ RSV } & F, G & SFV / DNA, RNA & Mouse & RSV protection & [86] \\
\hline & F, G & SFV / Particles & Mouse & RSV protection & [87] \\
\hline SARS-CoV & Glycoprotein & VEE / Particles & Mouse & SARS-CoV protection & [23] \\
\hline SEOV & M, S & SIN /Particles, DNA & Hamster & SEOV protection & [88] \\
\hline SHIV & env & SFV / Particles & Macaques & T cell prolif. Response & [89] \\
\hline Vaccinia & A33R, B5R & VEE / Particles & Mouse & Vaccinia protection & [31] \\
\hline
\end{tabular}

Abs: Antibodies; BVDV: Bovine viral diarrhea virus; CMI: Cell-mediated immune response; CSFV: Classical swine fever virus; CTL: Cytotoxic T-lymphocyte activity; EAV: Equine arteritis virus; HBV: Hepatitis B virus; HBC: Hepatitis C virus; HeV: Hendra virus; HIV: Human immunodeficiency virus; HPV: Human papillomavirus; HSV: Herpes simplex virus; IBDV: Infectious bursal disease virus; JEV: Japanese encephalitis virus; LIV: Loupin ill virus; MBGV: Marburg virus; MVE: Murray Valley encephalitis virus; NiV: Nipah virus; NLV: Norwalk-like virus; RSV: Respiratory syncytial virus; SARS-CoV: Severe acute respiratory syndrome corona virus; SEOV: Seoul virus; SFV: Semliki Forest virus; SHIV: Simian-human immunodeficiency virus; SIN: Sindbis virus; VEE: Venezuelan equine encephalitis virus

Table 1: Vaccine development for viral targets.

studies with VEE vectors in mice and guinea pigs demonstrated that protection could be achieved against challenges with some of the most feared viruses such as Ebola [18] and Lassa [19]. More recently, an alphavirus replicon (VEE) particle vaccine expressing the cluster IV H3N2 swine influenza HA gene demonstrated protection against challenges with homologous influenza virus [20]. In another study, VEE particles expressing the human influenza HA protein was demonstrated to generate high antibody titers in swine illustrating their potential use in vaccine development [21]. In attempts to improve the immunogenicity the herpes simplex virus type $1(\mathrm{HSV}-1)$ VP22 protein was fused to influenza HA from the H5N1 subtype [22]. Immunization studies demonstrated that both interleukin-4 (IL-4) of CD4+ T cells and interferon-gamma (IFN $\gamma)$ of $\mathrm{CD} 8+\mathrm{T}$ cells in vaccinated mice suggesting a promising approach for vaccine development against human-avian influenza viruses. Among the newly emerging viruses, the severe acute respiratory syndrome coronavirus (SARS-CoV) has 
been targeted for vaccine development applying VEE replicon particles [23]. VEE vaccinated aged mice showed protection against challenges with SARS-CoV. Moreover, a combined vaccine approach with SFV DNA vectors and recombinant adenovirus expressing the Classical Swine Fever Virus (CSFV) E2 glycoprotein demonstrated higher titers of neutralizing antibodies in pigs [24]. Challenges with the virulent CSFV Shimen strain showed no symptoms of viremia, for the combined vaccine, whereas immunization with adenovirus alone resulted in viremia in one pig of five. Glycoproteins from the zoonotic pathogenic Hendra Virus $(\mathrm{HeV})$ and Nipah Virus (NiV), which can cause fatal infections in both animals and humans, have been expressed from VEE particles to generate neutralizing antibodies [25]. Preliminary results indicated the approach enhanced the induction of cross-reactive neutralizing antibodies. In a study on Rift Valley Fever Virus (RVFV) both DNA plasmids and alphavirus replicons expressing the RVFV glycoprotein Gn fused to the C3d complement protein were applied for the vaccination of mice [26]. This strategy resulted in generation of neutralizing antibodies and provided protection against RVFV challenges. The plasmid DNA and alphavirus replicon approaches as well as the combined DNA prime/replicon boost strategy therefore shows great promise for valid RVFV vaccine development.

Sequential immunization with SIN and VEE replicon particles encoding the type1 HIV gp140 envelope (Env) and trimeric Env protein in MF59 adjuvant resulted in partial protection against highdose intravenous challenge with simian-human immunodeficiency virus (SHIV) in macaques [27]. More recently, it was shown that antibody-mediated protection could be extended to intramuscular and mucosal routes of delivery [28]. The immunization resulted in different degrees against subsequent mucosal SHIV challenge, but interestingly those macaques that were vaccinated intramuscularly with alphavirus replicon particles and boosted with Env protein were completely protected. Two SIN DNA vaccines expressing the hemagglutinin (pMSIN-H) and fusion proteins (pMSINH-FdU) elicited neutralizing antibodies, mucosal and systemic antibodysecreting cells, memory B cells and IFN $\gamma$ secreting T cells in cotton rats [29]. A one hundred percent protection against pulmonary measles was obtained after priming with pMSIN-H. In contrast, pMSINH-FdU priming gave protection only after live measles virus vaccine boost. Moreover, chimeric VEE/SIN replicon particles have been applied for the expression of hemagglutinin $(\mathrm{H})$ and fusion $(\mathrm{F})$ proteins of measles virus [30]. Intradermal vaccination of macaques resulted in hightiter neutralizing antibody and IFN $\gamma$-producing $\mathrm{T}$ cells. Challenges with wildtype measles virus $12-17$ months after vaccination showed protection from rash and viremia. In the need of safe and more efficient smallpox vaccines, VEE particles expressing the vaccinia virus A33R, B5R, A27L and L1R genes elicited protective immunity in vaccinated mice [31]. Likewise, immunization of macaques generated efficient antibody response and was able to neutralize and inhibit the spread of vaccinia and monkeypox viruses. Interestingly, a rabies virus vaccine study where SIN-based DNA encoding rabies glycoprotein $(\mathrm{G})$ was compared to a conventional rabies DNA vaccine and to Rabipur vaccine [32]. The replicon-based DNA vaccine induced better humoral and cell mediated immune responses than the conventional DNA vaccine in immunized mice. Moreover, complete protection was demonstrated against challenge with rabies virus CVS strain.

\section{Non-viral Targets}

In addition to viral targets a number of other infectious pathogens

\begin{tabular}{|l|l|l|l|l|l|}
\hline Agent & Target & Vector/Delivery & $\begin{array}{l}\text { Immu- } \\
\text { niza- } \\
\text { tion }\end{array}$ & Response & $\begin{array}{l}\text { Refer- } \\
\text { ence }\end{array}$ \\
\hline B. antracis & PA & SIN / Particles & Mouse & $\begin{array}{l}\text { B. antracis } \\
\text { protection }\end{array}$ & {$[37]$} \\
\hline B. abortus & IF3 & SFV / Particles & Mouse & $\begin{array}{l}\text { Brucella } \\
\text { protection }\end{array}$ & {$[36]$} \\
\hline C.botulinum & BoNTA-Hc & SFV / DNA & Mouse & $\begin{array}{l}\text { Abs, lym- } \\
\text { phoprolif }\end{array}$ & {$[35]$} \\
\hline Malaria & CS & SIN / Particles & Mouse & $\begin{array}{l}\text { Malaria } \\
\text { protection }\end{array}$ & {$[90]$} \\
\hline M. tuberculosis & Ag85A & SIN / DNA & Mouse & Protection & {$[34]$} \\
\hline P. falciparum & Ag Pf332 & SFV / Particles-RNA & Mouse & $\begin{array}{l}\text { Immunoligi- } \\
\text { cal memory }\end{array}$ & {$[33]$} \\
\hline Prion & NP & SFV / Particles & Mouse & $\begin{array}{l}\text { Monoclonal } \\
\text { Abs }\end{array}$ & {$[91]$} \\
\hline Staphylococcus & enterotox B & VEE / Particles & Mouse & Protection & {$[92]$} \\
\hline
\end{tabular}

Abs: Antibodies; SFV: Semliki Forest virus; SIN: Sindbis virus; VEE: Venezuelan equine encephalitis virus

Table 2: Vaccine development for non-viral infectious agents.

have been addressed as targets for vaccine development (Table 2). In this context, mice immunized with SFV vectors expressing the Plasmodium falciparum Pf332 antigen elicited immunological memory [33]. In another approach, SIN-based plasmid DNA vaccination with the Mycobacterium tuberculosis 85A antigen (Ag85A) provided strong immunity and resulted in long-term protection against $M$. tuberculosis challenges in mice [34]. Moreover, SFV DNA replicons were applied to express the botulinum neurotoxin A Hc gene (BoNTA-Hc) [35]. Both antibody and lymphoproliferative responses were obtained in $\mathrm{BALB} / \mathrm{c}$ mice. Co-expression of the granulocyte-macrophage colony-stimulating factor (GM-CSF) as an adjuvant enhanced immunogenicity. Replication-deficient SFV particles have also been used for immunization experiments in BALB/c mice for the Brucella abortus translation Initiation Factor 3 (IF3) [36]. It was demonstrated that mice challenged with the virulent $B$. abortus strain 2308 exhibited a significant level of resistance. Alternative forms of the protective antigen (PA) for Bacillus anthracis were expressed from SIN vectors [37]. Vaccination of Swiss Webster mice induced PA-specific IgG and neutralizing antibodies and also offered some protection against challenges with a lethal Ames strain.

\section{Tumor Vaccine Approaches}

Additional alphavirus applications are related to tumor vaccines (Table 3). One of the basic studies involved the immunization of mice with naked SFV RNA carrying the LacZ gene, which resulted in therapeutic efficacy [38]. Other vaccine approaches with SFV particles expressing the P1A gene [39] and VEE vectors carrying the Human Papilloma Virus (HPV) E7 gene [40] resulted in protection against further tumor development. In attempts to enhance the efficacy of HPV vaccines the adjuvant effect of interleukin-12 expressed from SFV vector was evaluated in mice [41]. Even a low dose of SFV-IL12 stimulated antigen-specific CTL responses and anti-tumor activity after SFV-based HPV16-E6E7 immunization. However, increased dosages did not improve these activities. Recently, alphavirus replicon-based expression of Melanoma Differentiation Antigen (MDA) tyrosine managed to prevent the growth of B16 transplantable melanoma [42]. It was demonstrated that the vaccine encoding tyrosine related protein 2 (TRP-2) relied on a novel immune mechanism, which required activation of both IgG and CD8+ cell effector responses. 


\begin{tabular}{|l|l|l|l|l|l|}
\hline Target & Gene & $\begin{array}{l}\text { Vector/De- } \\
\text { livery }\end{array}$ & $\begin{array}{l}\text { Immu- } \\
\text { niza- } \\
\text { tion }\end{array}$ & Response & $\begin{array}{l}\text { Refer- } \\
\text { ence }\end{array}$ \\
\hline $\begin{array}{l}\text { Brain } \\
\text { tumor }\end{array}$ & IL-12 & SFV / Particles & Mouse & Mouse & {$[93]$} \\
\hline $\begin{array}{l}\text { Cervical } \\
\text { cancer }\end{array}$ & HPVE6-E7 & SFV / Particles & Mouse & Tumor protection & {$[94]$} \\
\hline Glioma & B16, 203 & SFV / Particles & Mouse & Tumor protection & {$[95]$} \\
\hline Melanoma & MDA/trp-2 & VEE / Particles & Mouse & Therapeutic effect & {$[42]$} \\
\hline Tumor & B-galactosidase & SFV / RNA & Mouse & Tumor protection & {$[38]$} \\
\hline Tumor & HPVE7 & VEE / Particles & Mouse & Tumor protection & {$[40]$} \\
\hline Tumor & HPVE6E7+IL12 & SFV / Particles & Mouse & Anti-tumor activity & {$[41]$} \\
\hline Tumor & HPVE7-VP22 & SIN / Particles & Mouse & $\begin{array}{l}\text { CD8+ T-cell } \\
\text { response }\end{array}$ & {$[96]$} \\
\hline Tumor & IL-12 & SFV / Particles & Mouse & Tumor protection & {$[97]$} \\
\hline $\begin{array}{l}\text { Tumor } \\
\text { antigen }\end{array}$ & MHC class II & $\begin{array}{l}\text { SFV / Particles- } \\
\text { DNA }\end{array}$ & Mouse & Immunogenicity & {$[98]$} \\
\hline $\begin{array}{l}\text { Tumor } \\
\text { antigen }\end{array}$ & P185 & SFV / Particles & Mouse & $\begin{array}{l}\text { CTL, tumor pro- } \\
\text { tection }\end{array}$ & {$[39]$} \\
\hline $\begin{array}{l}\text { Tumor } \\
\text { antigen }\end{array}$ & trp-1 & SIN / DNA & Mouse & Antitumor activity & {$[99]$} \\
\hline CTL C & I9n & & & \\
\hline
\end{tabular}

CTL: Cytotoxic T-lymphocyte activity; HPV: Human papillomavirus; IL: interleukin MDA: Melanoma differentiation antigen; MHC: Major histocompatibility complex SFV: Semliki Forest virus; SIN: Sindbis virus; trp: tyrosine-related protein; VEE: Venezuelan equine encephalitis virus

Table 3: Vaccine development for cancer targets.

\section{Clinical Trials for Alphavirus Vaccines}

Despite the numerous studies conducted in various animal models very few evaluations have been carried out with alphaviruses in humans. The first clinical trial for SFV relates to intravenous administration of liposome encapsulated particles in melanoma and kidney carcinoma patients [43]. The first vaccine-related alphavirus study was a Phase I randomized, double-blind clinical trial for cytomegalovirus (CMV) [44]. A two component vaccine expressing CMV gB or pp65/1E1 fusion protein was administered intramuscularly or subcutaneously in CMV seronegative adult volunteers. The vaccine was well tolerated showing only mild to moderate local reactogenicity and no clinical important changes. The immunization induced neutralizing antibody and multifunctional $\mathrm{T}$ cell responses against CMV antigens. In another study, it was shown that alphavirus particles, which efficiently infect dendritic cells, could be repeatedly administered to patients with metastatic cancer expressing the Carcino Embryonic Antigen (CEA) [45]. Moreover, CEA-specific antibodies were capable of mediating antibody-dependent cellular cytotoxicity against tumor cells from human colorectal cancer metastases. Most encouragingly, patients with CEA-specific antibodies showed extended overall survival.

\section{Recent Vector Development}

It is appropriate in this review to describe some recent development of alphavirus vector applications. It was demonstrated that when VEE replicon particles without any transgene were used as adjuvant for an inactivated influenza vaccine in rhesus monkeys, the influenza-specific CD4+ T-cell responses were 4.4 fold higher and the virus-specific IFN $\gamma$ and IL-2 producing CD4+ T cells were enhanced 7.6 and 5.3 fold, respectively [46]. In summary, the VEE replicon particles used as adjuvant dramatically improved the immunogenicity and protection against challenges with the human seasonal influenza isolate A/ Memphis/7/2001 (H1N1). In another study, alphavirus adjuvants were co-administered with mouse-tropic norovirus (MNV)-like particle vaccine [47]. These multivalent vaccinations significantly reduced the viral load of MNV suggesting that the humoral immunity may protect against challenges with heterologous noroviruses. Furthermore, VEE replicons were shown to possess adjuvant activity and induced an increased and balanced IgG subtype response, which also increased augmented systemic and mucosal antigen-specific CD8+ $\mathrm{T}$ cell responses [48]. This approach provides the potential molecular basis for alphavirus-induced immunity and improvement in alphavirusbased vaccines.

Chimeric VEE-SIN vectors for the expression of measles virus hemagglutinin (VEE/SIN-H) have been compared to a non-formalininactivated alum-precipitated measles vaccine (FI-MV) [49]. Although the MV-specific IgG levels were similar, the VEE/SIN-H antibodies showed neutralizing activity. Spontaneous ex vivo production of IFN $\gamma$ and IL-4 was observed in induced T cells after immunization with VEE/ SIN-H, whereas vaccination with FI-MV-induced T cells generated IL-4 only after stimulation. In another approach vaccine vectors were constructed based on live recombinant Vesicular Stomatitis Virus (VSV) and an SFV replicon that propagates through expression of the VSV glycoprotein $(G)$ [50]. Applying these vectors for the expression of Simian Immunodeficiency Virus (SIV) gag and env proteins in vaccinated macaques resulted in protection against challenges with lethal doses of SIV. Recently, it was demonstrated that a heterologous prime-boost approach with recombinant SFV encoding a HPV E6-E7 fusion protein and virosomes containing HPV E7 resulted in higher numbers of antigen-specific CTL in mice than applying homologous protocols [51]. However, the higher frequency of central memory $\mathrm{T}$ cells after homologous immunization, which is crucial for cancer vaccines, indicates that the superiority in number of antigen-specific CTL observed after heterologous prime-boost immunization should not be overestimated.

\section{Vaccines against Alphaviruses}

In the context of alphavirus vaccines a large portion has dealt with generating vaccines against various alphaviruses (Table 4). For instance, $\mathrm{BALB} / \mathrm{c}$ mice vaccinated with an attenuated VEE strain resulted in protection against airborne virus [52]. Furthermore, the live attenuated V3526 VEE vaccine showed improved protection against VEE challenges [53]. Likewise, C57BL/6 mice demonstrated complete protection against lethal challenges with a virulent Eastern Equine Encephalitis (EEE) virus strain after vaccination with a chimeric EEE and Western Equine Encephalitis (WEE) virus [54]. A live Chikungunya (CHIK) tested in a human Phase II trial demonstrated generation of neutralizing antibodies [55].

A new approach for designing attenuated alphaviruses has been

\begin{tabular}{|l|l|l|l|l|l|}
\hline Virus & Gene & Vector Delivery & $\begin{array}{l}\text { Immuniza- } \\
\text { tion }\end{array}$ & Response & Reference \\
\hline $\begin{array}{l}\text { CHIK } \\
\text { Abs }\end{array}$ & TSI-GSD-218 & CHIK Infection & Human & Neutralizing & {$[55]$} \\
\hline CHIK & Glyocprotein & CHIK Infection & Macaques & $\begin{array}{l}\text { Neutralizing } \\
\text { Abs }\end{array}$ & {$[58]$} \\
\hline EEE & EEE/WEE & EEE Infection & Mouse & EEE protection & {$[54]$} \\
\hline VEE & VEE att & VEE Infection & Mouse & $\begin{array}{l}\text { VEE protec- } \\
\text { tionc }\end{array}$ & {$[100]$} \\
\hline VEEc & VEE V3526 & VEE V3526 & Mouse & VEE protection & {$[101]$} \\
\hline VEE & VEE TC-83 & VEE Infection & Mouse & VEE protection & {$[102]$} \\
\hline VEE & $26 S$ & VEE Infection & Macaques & VEE protection & {$[59]$} \\
\hline WNV & WNV att & WNV Nanopatch & Mouse & Abs & {$[60]$} \\
\hline
\end{tabular}

Abs: Antibodies; att: attenuated; CHIK: Chikungunuya virus; EEE: Eastern equine encephalitis virus; SFV: Semliki Forest virus; SIN: Sindbis virus; VEE: Venezuelan equine encephalitis virus; WNV: West Nile virus

Table 4: Vaccine development against alphaviruses. 
to tackle the mechanisms of replication and virus-host interaction. Variants of CHIK envelope lacking important contributors to viral pathogenesis were made incapable of transmission by mosquito vectors by making their replication dependent on internal ribosome entry sites (IRES) [56]. This engineering prevented replication on cells of mosquito origin, whereas the replication occurred efficiently in Vero cells. In another study, chimeric vaccine candidates were engineered applying the non-structural genes of either the attenuated VEE strain TC- 83 or a naturally attenuated EEV strain and the structural genes of CHIK [57]. The vaccines showed significantly lower infection of Aedes aegypti and A. albopictus, the common urban vectors for CHIK, which suggested a low risk of transmission. A synthetic DNA vaccine expressing a component of the envelope glycoprotein was engineered based on a new CHIK virus isolated from an acutely infected human patient [58]. In vivo electroporation induced robust antigen-specific cellular and humoral immune responses and provided protection against CHIK challenge in mice. Additionally, studies in macaques showed induction of neutralizing antibodies similar to those found in convalescent human patient sera.

Nonhuman primates were subjected to a VEE DNA vaccine in an aerosol model, where the VEE 26S structural genes were expressed from a DNA vector [59]. No viremia was detected in two out of three vaccinated macaques, while one animal showed low viremia. In contrast, control animals demonstrated high viremia.

In the area of vaccine delivery, the Nanopatch comprised of arrays of densely packed projections has been applied for skin vaccination of West Nile Virus and CHIK in mice [60]. The goal was to target epidermal and dermal antigen presenting cells (APCs). The efficiency of Nanopatch delivery was demonstrated using an inactivated whole CHIK vaccine and a DNA-based attenuated West Nile Virus vaccine. This approached offered needle-free, highly effective and inexpensive vaccine delivery.

The discovery of gene silencing as a common phenomenon in biology has had a major impact on all areas of drug discovery. Not surprisingly, efforts to apply RNA interference have also reached vaccine development. In this context, the efficiency of small interfering RNAs (siRNAs) against CHIK replication has been investigated in Vero cells [61]. Two siRNAs against the conserved regions nsP3 and E1 genes showed a reduction of virus titer up to $99.6 \%$. The effect was most prominent at $24 \mathrm{~h} \mathrm{(99 \% )}$ and still significant at $48 \mathrm{~h}(65 \%)$ and might present a new therapeutic approach. Moreover, microRNA (miRNA) specific target sequences have been introduced into alphavirus helper RNAs used for replicon particle production (see Figure 1) [62]. Interestingly, particles were efficiently produced when miRNA-specific inhibitors were present. However in their absence, cellular miRNAs down-regulated helper RNA replication in vitro. When replicon RNA with miRNAs incorporated into the sequence was administered in mice, cellular miRNAs were able to prevent the replication of replicon RNA. These results suggest the feasibility of potentially using miRNA for the inhibition of viral replication as a therapeutic approach.

\section{Conclusions}

As described above a number of vaccine development studies have been carried out using mainly the three most commonly applied alphavirus vectors, SFV, SIN and VEE. Interestingly, these vectors have been used as replicon particles, naked RNA and layered DNA vectors. The results indicate that each approach has generated responses in the form of cellular or humoral responses and in many cases protection against challenges with lethal doses of virus (Table 1) and other non-viral agents (Table 2). Furthermore, protection against tumor challenges has been successfully achieved (Table 3), which bodes well for future preventive vaccination against cancer. Obviously, as alphaviruses themselves are pathogens causing epidemics [2-4], they are credible targets for vaccine development. A number of studies have been conducted, particularly for VEE and CHIK (Table 4), which have indicated the feasibility of generating efficient vaccines providing protection against challenges with virulent alphavirus strains.

Application of alphavirus vectors for vaccine development requires the addressing of biosafety issues. Although certain alphaviruses have been the cause of global fever epidemics [2-4] the strains used in vaccine development have most commonly been attenuated. Furthermore, second generation helper vectors [103] or split helper systems [104] have been used for the generation of replication-deficient alphavirus particles to ensure that no wild-type like replication-proficient particles are produced through homologous recombination. The safe application of SFV vectors in humans was first demonstrated in a phase I trial in melanoma and kidney carcinoma patients [43]. Repeated intravenous administration showed no SFV related toxicity or adverse reactions. Obviously, the use of naked RNA or layered DNA vectors presents no biosafety risk as no infectious viral particles are produced at any stage of the immunization procedure. Most encouragingly, the positive outcome of the first clinical trials with alphavirus replicons will further boost additional studies.

In summary, the ease of generating naked RNA, layered DNA vectors and recombinant particles are great assets in vaccine development. Alphavirus vectors provide rapid transgene expression of a transient nature, which makes them attractive as efficient gene delivery vehicles. However, their full potential has not yet been employed and future development will provide excellent opportunities for the generation of new and efficient vaccines.

\section{References}

1. Strauss JH, Strauss EG (1994) The alphaviruses: gene expression, replication and evolution. Microbial Rev 58: 491-562.

2. Kelvin AA (2011) Outbreak of Chikungunya in the Republic of Congo and the global picture. J Infect Dev Ctries 5: 441-444.

3. Mathiot CC, Grimaud G, Garry P (1990) An outbreak of Semliki Forest virus infections in Central African Republic. Am J Trop Med Hyg 42: 386-393.

4. Weaver SC, Salas R, Rico-Hesse R (1996) Remergence of epidemic Venezuelan equine encephalomyelitis in South America. VEE Study Group. Lancet 348: 436-440.

5. Liljeström P, Garoff H (1991) A new generation of animal cell expression vectors based on the Semliki Forest virus replicon. Bio/Technology 9: 1356-1361.

6. Xiong C, Levis R, Shen P, Schlesinger, S, Rice CM, et al. (1989) Sindbis virus: an efficient, broad host range vector for gene expression in animal cells. Science 243: 1188-1191.

7. Davis NL, Brown KW, Johnston RE (1989) In vitro synthesis of infectious Venezuelan equine encephalitis virus RNA from a cDNA clone: analysis of a viable deletion mutant. Virol 171: 189-204

8. Lundstrom K, Schweizer C, Rotmann D, Hermann D, Schneider EM (2001) Semliki Forest virus vectors: efficient vehicles for in vitro and in vivo gene delivery. FEBS Lett 504: 99-103.

9. Lundstrom K (2003) Semliki Forest virus vectors for rapid and high-leve expression of integral membrane proteins. Biochim Biophys Acta 1610: 90-96.

10. Ehrengruber MU, Lundstrom K, Schweitzer C, Heuss C, Schlesinger S. et al. (1999) Recombinant Semliki Forest virus and Sindbis virus infect efficiently neurons in hippocampal slice cultures. Proc Natl Acad Sci USA 96: 7041-7046.

11. Lundstrom K, Richards JG, Pink JR, Jenck F (1999) Efficient in vivo expression of a reporter gene in rat brain after injection of recombinant replication-deficient Semliki Forest virus. Gene Ther Mol Biol 3: 15-23. 
12. Lundstrom K (2003) Alphavirus vectors for vaccine production and gene therapy. Exp Rev Vacc 2: 447-459.

13. Malone JG, Berglund PJ, Liljestrom P, Rhodes GH, Malone RW (1997) Mucosal immune responses associated with polynucleotide vaccination. Behring Inst Mitt 98: 63-72.

14. Schultz-Cherry S, Dybing JK, Davis NL, Williamson C, Suarez DL et al. (2000) Influenza virus (A/HK/156/97) hemagglutinin expressed by an alphavirus replicon system protects against lethal infection with Hong Kong-origin H5N1 viruses. Virol 278: 55-59.

15. Brand D, Lemiale F, Turbica I, Buzelay L, Brunet S et al. (1998) Comparative analysis of humoral immune responses to HIV type 1 envelope glycoproteins in mice immunized with a DNA vaccine, recombinant Semliki Forest virus RNA or recombinant Semliki Forest virus particles. AIDS Res Hum Retroviruses 14:1369-1377

16. Giraud A, Ataman-Onal Y, Battail N, Piga N, Brand D et al. (1999) Generation of monoclonal antibodies to native human immunodeficiency virus type 1 envelope glycoprotein by immunization of mice with naked RNA. J Virol Methods 79: 75-84

17. Caley IJ, Betts MR, Irlbeck DM, Davis NL, Swanstrom R et al. (1997) Humoral mucosal, and cellular immunity in response to a human immunodeficiency virus type 1 immunogen expressed by a Venezuelan equine encephalitis virus vaccine vector. J Virol. 71: 3031-3038

18. Wilson JA, Hart MK (2001) Protection from Ebola virus mediated by cytotoxic T-lymphocytes specific for the viral nucleoprotein. J Virol 75: 2660-2664.

19. Pushko P, Parker M, Ludwig GV, Davis NL, Johnston RE et al. (1997) Replicon-helper systems from attenuated Venezuelan equine encephalitis virus: expression of heterologous genes in vitro and immunization against heterologous pathogens in vivo. Virol 239: 389-401.

20. Bosworth B, Erdman MM, Stine DL, Harris I, Irwin C et al. (2010) Replicon particle vaccine protects swine against influenza. Comp Immunol Microbiol Infect Dis. 33: e99-e103.

21. Erdman MM, Kamrud KI, Harris DL, Smith J (2010) Alphavirus replicon particle vaccines developed for use in humans induce high levels of antibodies to influenza virus hemagglutinin in swine: proof of concept. Vaccine 28: 594-596.

22. Yang SG, Wo JE, Li MW, Mi FF, Yu CB et al. (2009) Construction and cellular immune response induction of $\mathrm{HA}$-based alphavirus replicon vaccines against human-avian influenza (H5N1).Vaccine 27: 7451-7458.

23. Sheahan T, Whitmore A, Long K, Ferris M, Rockx B et al. (2011) Successfu vaccination strategies that protect aged mice from lethal challenge from influenza virus and heterologous severe acute respiratory syndrome coronavirus. J Virol 85: 217-230.

24. Sun Y, Li N, Li HY, Li M, Qiu HJ (2010) Enhanced immunity against classical swine fever in pigs induced by prime-boost immunization using an alphavirus replicon-vectored DNA vaccine and a recombinant adenovirus. Vet Immunol Immunopathol 137: 20-27.

25. Defang GN, Khetawat D, Broder CC, Quinnan GV Jr. (2010) Induction of neutralizing antibodies to Hendra and Nipah glycoproteins using a Venezuelan equine encephalitis virus in vivo expression system. Vaccine 29: 212-220.

26. Bhardwaj N, Heise MT, Ross TM (2010) Vaccination with DNA plasmids expressing $\mathrm{Gn}$ coupled to $\mathrm{C} 3 \mathrm{~d}$ or alphavirus replicons expressing gn protects mice against Rift Valley fever virus. PLoS Negl Trop Dis 4: e725.

27. Xu R, Srivastava IK, Greer CE, Zarkikh I, Kraft Z, et al. (2006) Characterization of immune responses elicited in macaques immunized sequentially with chimeric VEE/SIN alphavirus replicon particles expressing SIVGag and/or HIVEnv and with recombinant HIVgp140Env protein. AIDS Res Hum Retroviruses 22: 10221030.

28. Barnett SW, Burke B, Sun Y, Kan E, Legg H et al. (2010) Antibody-mediated protection against mucosal simian-human immunodeficiency virus challenge of macaques immunized with alphavirus replicon particles and boosted with trimeric envelope glycoprotein in MF59 adjuvant. J Virol 84: 5975-585.

29. Pasetti MF, Ramirez K, Resendiz-Albor A, Ulmer J, Barry EM et al. (2009) Sindbis virus-based measles DNA vaccines protect cotton rats against respiratory measles: relevance of antibodies, mucosal and systemic antibodysecreting cells, memory B cells, and Th1-type cytokines as correlates of immunity. J Virol 83: 2789-2794.

30. Pan CH, Greer CE, Hauer D, Legg HS, Lee EY et al. (2010) A chimeric alphavirus replicon particle vaccine expressing the hemagglutinin and fusion proteins protects juvenile and infant rhesus macaques from measles. J Virol 84: 3798-3807.

31. Hooper JW, Ferro AM, Golden JW, Silvera P, Dudek J et al. (2009) Molecula smallpox vaccine delivered by alphavirus replicons elicits protective immunity in mice and non-human primates. Vaccine 28: 494-511.

32. Saxena S, Dahiya SS, Sonwane AA, Patel CL, Saini M et al. (2008) A sindbis virus replicon-based DNA vaccine encoding the rabies virus glycoprotein elicits immune responses and complete protection in mice from lethal challenge. Vaccine 26: 6592-6601

33. Andersson C, Vasconcelos NM, Sievertzon M, Haddad D, Liljeqvist S (2001) Comparative immunization study using RNA and DNA constructs encoding a part of the Plasmodium falciparum antigen Pf332. Scand J Immunol 54: 117124

34. Kirman JR, Turon T, Su H, Li A, Kraus C, et al. (2003) Enhanced immunogenicity to Mycobacterium tuberculosis by vaccination with an alphavirus plasmid replicon expressing antigen 85A. Infect Immun 71: 575-579.

35. Li N, Yu YZ, Yu WY, Sun ZW (2011) Enhancement of the immunogenicity of DNA replicon vaccine of Clostridium botulinum neurotoxin serotype A by GMCSF gene adjuvant. Immunopharmacol Immunotoxicol 33: 211-219.

36. Cabrera A, Sáez D, Céspedes S, Andrews E, Oñate A (2009) Vaccination with recombinant Semliki Forest virus particles expressing translation initiation factor 3 of Brucella abortus induces protective immunity in BALB/c mice. Immunobiology 214: 467-474.

37. Thomas JM, Moen ST, Gnade BT, Vargas-Inchaustegui DA, Foltz SM, et al. (2009) Recombinant Sindbis virus vectors designed to express protective antigen of Bacillus anthracis protect animals from anthrax and display synergy with ciprofloxacin. Clin Vaccine Immunol 16: 1696-1699.

38. Ying H, Zaks TZ, Wang RF, Irvine KR, Kammula US et al. (1999) Cancer therapy using a self-replicating RNA vaccine. Nat Med 5: 823-827.

39. Colmenero P, Liljeström P, Jondal M. (1999) Induction of P815 tumor immunity by recombinant Semliki Forest virus expressing the P1A gene. Gene Ther 6 : 1728-1733.

40. Velders MP, McElhiney S, Cassetti MC, Eiben GL, Higgins T et al. (2001) Eradication of established tumors by vaccination with Venezuelan equine encephalitis virus replicon particles delivering human papillomavirus 16 E7 RNA. Cancer Res 61: 7861-7867.

41. Riezebos-Brilman A, Regts J, Chen M, Wilschut J, Daemen T (2009) Augmentation of alphavirus vector-induced human papilloma virus-specific immune and anti-tumour responses by co-expression of interleukin-12. Vaccine 27: 701-707.

42. Avogadri F, Merghoub T, Maughan MF, Hirschhorn-Cymerman D, Morris $J$ et al. (2010) Alphavirus replicon particles expressing TRP-2 provide potent therapeutic effect on melanoma through activation of humoral and cellular immunity. PLoS One 5: e12670.

43. Lundstrom K. (2005) Biology and application of alphaviruses in gene therapy. Gene Ther 12: S92-S97.

44. Bernstein DI, Reap EA, Katen K, Watson A, Smith K, et al. (2009) Randomized double-blind, Phase 1 trial of an alphavirus replicon vaccine for cytomegalovirus in CMV seronegative adult volunteers. Vaccine 28: 484-493.

45. Morse MA, Hobeika AC, Osada T, Berglund P, Hubby B, et al. (2010) An alphavirus vector overcomes the presence of neutralizing antibodies and elevated numbers of Tregs to induce immune responses in humans with advanced cancer. J Clin Invest 120: 3234-3241.

46. Carroll TD, Matzinger SR, Barro M, Fritts L, McChesney MB, et al. (2011) Alphavirus replicon-based adjuvants enhance the immunogenicity and effectiveness of Fluzone ${ }^{\circledR}$ in rhesus macaques. Vaccine 29: 931-940.

47. LoBue AD, Thompson JM, Lindesmith L, Johnston RE, Baric RS (2009) Alphavirus-adjuvanted norovirus-like particle vaccines: heterologous, humoral, and mucosal immune responses protect against murine norovirus challenge. J Virol 83: 3212-3227.

48. Thompson JM, Whitmore AC, Staats HF, Johnston RE (2008) Alphavirus replicon particles acting as adjuvants promote CD8+ $T$ cell responses to codelivered antigen. Vaccine 26: 4267-4275.

49. Bergen MJ, Pan CH, Greer CE, Legg HS, Polo JM, et al. (2010) Comparison of 
the immune responses induced by chimeric alphavirus-vectored and formalininactivated alum-precipitated measles vaccines in mice. PLoS One 5: e10297.

50. Schell JB, Rose NF, Bahl K, Diller K, Buonocore L, et al. (2011) Significan protection against high-dose simian immunodeficiency virus challenge conferred by a new prime-boost vaccine regimen. J Virol 85: $5764-5772$

51. Walczak M, de Mare A, Riezebos-Brilman A, Regts J, Hoogeboom BN, et al. (2011) Heterologous prime-boost immunizations with a virosomal and an alphavirus replicon vaccine. Mol Pharm 8: 65-77.

52. Bennett AM, Elvin SJ, Wright AJ, Jones SM, Phillpotts RJ (2000) An immunological profile of Balb/c mice protected from airborne challenge following vaccination with a live attenuated Venezuelan equine encephalitis virus vaccine. Vaccine 19: 337-347.

53. Hart MK, Caswell-Stephan K, Bakken R, Tammariello R, Pratt W, et al. (2000) Improved mucosal protection against Venezuelan equine encephalitis virus is induced by the molecularly defined, live-attenuated V3526 vaccine candidate. Vaccine 18: 3067-3075.

54. Schoepp RJ, Smith JF, Parker MD (2002) Recombinant chimeric western and eastern equine encephalitis viruses as potential vaccine candidates. Virology 302: 299-309.

55. Edelman R, Tacket CO, Wasserman SS, Bodison SA, Perry JG, et al. (2000) Phase II safety and immunogenicity study of live chikungunya virus vaccine TSI-GSD-218. Am J Trop Med Hyg 62: 681-685.

56. Kim DY, Atasheva S, Foy NJ, Wang E, Frolova El, et al. (2011) Design of chimeric alphaviruses with a programmed, attenuated, cell type-restricted phenotype. J Virol 85: 4363-4376.

57. Darwin JR, Kenney JL, Weaver SC (2011) Transmission potential of two chimeric Chikungunya vaccine candidates in the urban mosquito vectors, Aedes aegypti and Ae. albopictus. Am J Trop Med Hyg 84: 1012-1015.

58. Mallilankaraman K, Shedlock DJ, Bao H, Kawalekar OU, Fagone P, et al. (2011) A DNA vaccine against chikungunya virus is protective in mice and induces neutralizing antibodies in mice and nonhuman primates. PLoS Negl Trop Dis 5: e928.

59. Dupuy LC, Richards MJ, Reed DS, Schmaljohn CS (2010) Immunogenicity and protective efficacy of a DNA vaccine against Venezuelan equine encephalitis virus aerosol challenge in nonhuman primates. Vaccine 28: 7345-7350.

60. Prow TW, Chen X, Prow NA, Fernando GJ, Tan CS, et al. (2010) Nanopatchtargeted skin vaccination against West Nile Virus and Chikungunya virus in mice. Small 6: 1776-1784.

61. Dash PK, Tiwari M, Santhosh SR, Parida M, Lakshmana Rao PV (2008) RNA interference mediated inhibition of Chikungunya virus replication in mammalian cells. Biochem Biophys Res Commun 376: 718-722.

62. Kamrud KI, Coffield VM, Owens G, Goodman C, Alterson K, et al. (2010) In vitro and in vivo characterization of microRNA-targeted alphavirus replicon and helper RNAs. J Virol 84: 7713-7725

63. Reddy JR, Kwang J, Varthakavi V, Lechtenberg KF, Minocha HC (1999) Semiliki forest virus vector carrying the bovine viral diarrhea virus NS3 (p80) cDNA induced immune responses in mice and expressed BVDV protein in mammalian cells. Comp Immunol Microbiol Infect Dis 22: 231-246.

64. Balasuriya UB, Heidner HW, Hedges JF, Williams JC, Davis NL, et al. (2000) Expression of the two major envelope proteins of equine arteritis virus as a heterodimer is necessary for induction of neutralizing antibodies in mice immunized with recombinant Venezuelan equine encephalitis virus replicon particles. J Virol 74: 10623-10630.

65. Pushko P, Bray M, Ludwig GV, Parker M, Schmaljohn A, et al. (2000) Recombinant RNA replicons derived from attenuated Venezuelan equine encephalitis virus protect guinea pigs and mice from Ebola hemorrhagic fever virus. Vaccine 19: 142-153

66. Wilson JA, Bray M, Bakken R, Hart MK (2001) Vaccine potential of Ebola virus VP24, VP30, VP35, and VP40 proteins. Virology 286: 384-390.

67. Driver DA, Latham EM, Polo JM, Belli BA, Banks TA, et al. (1995) Layered amplification of gene expression with a DNA gene delivery system. Ann N Y Acad Sci 772: 261-264

68. Vidalin O, Fournillier A, Renard N, Chen M, Depla E, et al. (2000) Use of conventional or replicating nucleic acid-based vaccines and recombinant
Semliki forest virus-derived particles for the induction of immune responses against hepatitis $C$ virus core and E2 antigens. Virology 276: 259-270.

69. Brinster C, Chen M, Boucreux D, Paranhos-Baccala G, Liljeström P, et al (2002) Hepatitis C virus non-structural protein 3-specific cellular immune responses following single or combined immunization with DNA or recombinant Semliki Forest virus particles. J Gen Virol 83: 369-381.

70. Hsu KF, Hung CF, Cheng WF, He L, Slater LA, et al. (2001) Enhancemen of suicidal DNA vaccine potency by linking Mycobacterium tuberculosis heat shock protein 70 to an antigen. Gene Ther 8: 376-383.

71. Cheng WF, Hung CH, Chai CY, Hsu KF, He L, et al. (2001) Enhancement of sindbis virus self-replicating RNA vaccine potency by linkage of herpes simplex virus type 1 VP22 protein to antigen. J Virol 75: 2368-2376.

72. Cheng WF, Hung CF, Chai CY, Hsu KF, He L, et al. (2001) Enhancement of Sindbis virus self-replicating RNA vaccine potency by linkage of Mycobacterium tuberculosis heat shock protein 70 gene to an antigen gene. J Immunol 166: 6218-6226.

73. Schlesinger S, Dubensky TW (1999) Alphavirus vectors for gene expression and vaccines. Curr Opin Biotechnol 10: 434-439.

74. Hariharan MJ, Driver DA, Townsend K, Brumm D, Polo JM, et al. (1998) DNA immunization against herpes simplex virus: enhanced efficacy using a Sindbis virus-based vector. J Virol 72: 950-958.

75. Phenix KV, Wark K, Luke CJ, Skinner MA, Smyth JA, et al. (2001) Recombinan Semliki Forest virus vector exhibits potential for avian virus vaccine development. Vaccine 19: 3116-3123

76. Berglund P, Smerdou C, Fleeton MN, Tubulekas I, Liljeström P (1998) Enhancing immune responses using suicidal DNA vaccines. Nat Biotechnol 16: $562-565$

77. Zhou X, Berglund P, Rhodes G, Parker SE, Jondal M, et al. (1994) Selfreplicating Semliki Forest virus RNA as recombinant vaccine. Vaccine 12 1510-1514.

78. Vignuzzi M, Gerbaud S, van der Werf S, Escriou N (2001) Naked RNA immunization with replicons derived from poliovirus and Semliki Forest virus genomes for the generation of a cytotoxic $T$ cell response against the influenza A virus nucleoprotein. J Gen Virol 82: 1737-1747.

79. Pugachev KV, Mason PW, Shope RE, Frey TK (1995) Double-subgenomic Sindbis virus recombinants expressing immunogenic proteins of Japanese encephalitis virus induce significant protection in mice against lethal JEV infection. Virology 212: 587-594.

80. Fleeton MN, Liljeström P, Sheahan BJ, Atkins GJ (2000) Recombinant Semlik Forest virus particles expressing louping ill virus antigens induce a better protective response than plasmid-based DNA vaccines or an inactivated whole particle vaccine. J Gen Virol 81: 749-758.

81. Morris-Downes MM, Phenix KV, Smyth J, Sheahan BJ, Lileqvist S, et al. (2001) Semliki Forest virus-based vaccines: persistence, distribution and pathological analysis in two animal systems. Vaccine 19: 1978-1988.

82. Hevey M, Negley D, VanderZanden L, Tammariello RF, Geisbert J, et al. (2001) Marburg virus vaccines: comparing classical and new approaches. Vaccine 20 586-593.

83. Hevey M, Negley D, Pushko P, Smith J, Schmaljohn A (1998) Marburg virus vaccines based upon alphavirus replicons protect guinea pigs and nonhuman primates. Virology 251: 28-37.

84. Colombage G, Hall R, Pavy M, Lobigs M (1998) DNA-based and alphavirusvectored immunisation with prM and $E$ proteins elicits long-lived and protective immunity against the flavivirus, Murray Valley encephalitis virus. Virology 250: 151-163.

85. Harrington PR, Yount B, Johnston RE, Davis N, Moe C, et al. (2002) Systemic mucosal, and heterotypic immune induction in mice inoculated with Venezuelan equine encephalitis replicons expressing Norwalk virus-like particles. J Virol 76: $730-742$

86. Fleeton MN, Chen M, Berglund P, Rhodes G, Parker SE, et al. (2001) Selfreplicative RNA vaccines elicit protection against influenza $A$ virus, respiratory syncytial virus, and a tickborne encephalitis virus. J Infect Dis 183: 1395-1398.

87. Chen M, Hu KF, Rozell B, Orvell C, Morein B, et al. (2002) Vaccination with recombinant alphavirus or immune-stimulating complex antigen against respiratory syncytial virus. J Immunol 169: 3208-3216. 
88. Kamrud KI, Hooper JW, Elgh F, Schmaljohn CS (1999) Comparison of the protective efficacy of naked DNA, DNA-based Sindbis replicon, and packaged Sindbis replicon vectors expressing Hantavirus structural genes in hamsters. Virology 263: 209-219.

89. Berglund P, Quesada-Rolander M, Putkonen P, Biberfeld G, Thorstensson R, et al. (1997) Outcome of immunization of cynomolgus monkeys with recombinant Semliki Forest virus encoding human immunodeficiency virus type 1 envelope protein and challenge with a high dose of SHIV-4 virus. AIDS Res Hum Retroviruses 13: 1487-1495.

90. Tsuji M, Bergmann CC, Takita-Sonoda Y, Murata K, Rodrigues EG, et al. (1998) Recombinant Sindbis viruses expressing a cytotoxic T-lymphocyte epitope of a malaria parasite or of influenza virus elicit protection against the corresponding pathogen in mice. J Virol 72: 6907-6910.

91. Krasemann S, Jürgens T, Bodemer W (1999) Generation of monoclonal antibodies against prion proteins with an unconventional nucleic acid-based immunization strategy. J Biotechnol 73: 119-129.

92. Lee JS, Dyas BK, Nystrom SS, Lind CM, Smith JF et al. (2002) Immune protection against staphylococcal enterotoxin-induced toxic shock by vaccination with a Venezuelan equine encephalitis virus replicon. J Infect Dis 185: $1192-1196$

93. Yamanaka R, Zullo SA, Ramsey J, Yajima N, Tsuchiya N, et al. (2002) Marked enhancement of antitumor immune responses in mouse brain tumor models by genetically modified dendritic cells producing Semliki Forest virus-mediated interleukin-12. J Neurosurg 97: 611-618.

94. Daemen T, Regts J, Holtrop M, Wilschut J (2002) Immunization strategy against cervical cancer involving an alphavirus vector expressing high levels of a stable fusion protein of human papillomavirus 16 E6 and E7. Gene Ther 9: 85-94.

95. Yamanaka R, Zullo SA, Tanaka R, Ramsey J, Blaese M, et al. (2000) Induction of a therapeutic antitumor immunological response by intratumoral injection of genetically engineered Semliki Forest virus to produce interleukin-12. Neurosurg Focus 9: e7.
96. Cheng WF, Hung CF, Hsu KF, Chai CY, He L, et al. (2002) Cancer immunotherapy using Sindbis virus replicon particles encoding a VP22-antigen fusion. Hum Gene Ther 13: 553-568.

97. Colmenero P, Chen M, Castaños-Velez E, Liljeström P, Jondal M (2002) Immunotherapy with recombinant SFV-replicons expressing the P815A tumor antigen or IL-12 induces tumor regression. Int J Cancer 98: 554-560.

98. Ying H, Zeng G, Black KL (2001) Innovative cancer vaccine strategies based on the identification of tumour-associated antigens. BioDrugs 15: 819-831.

99. Leitner WW, Hwang LN, deVeer MJ, Zhou A, Silverman RH, et al. (2003) Alphavirus-based DNA vaccine breaks immunological tolerance by activating innate antiviral pathways. Nat Med 9: 33-39.

100. Bennett AM, Elvin SJ, Wright AJ, Jones SM, Phillpotts RJ (2000) An immunological profile of Balb/c mice protected from airborne challenge following vaccination with a live attenuated Venezuelan equine encephalitis virus vaccine. Vaccine 19: 337-347.

101. Hart MK, Caswell-Stephan K, Bakken R, Tammariello R, Pratt W, et al. (2000) Improved mucosal protection against Venezuelan equine encephalitis virus is induced by the molecularly defined, live-attenuated V 3526 vaccine candidate. Vaccine 18: 3067-3075

102. Elvin SJ, BennettAM, Phillpotts RJ (2002) Role for mucosal immune responses and cell-mediated immune functions in protection from airborne challenge with Venezuelan equine encephalitis virus. J Med Virol 67: 384-393.

103. Berglund P, Sjöberg M, Garoff H, Atkins GJ, Sheahan BJ, et al. (1993) Semlik Forest virus expression system: production of conditionally infectious particles. Biotechnology (NY) 11: 916-920.

104. Smerdou C, Liljeström P (1999) Two-helper RNA system for production of recombinant Semliki Forest virus particles. J Virol 73: 1092-1098. 